\title{
The involvement of glutamate dehydrogenase and glutamine synthetase/glutamate synthase in ammonia assimilation by the basidiomycete fungus Stropharia semiglobata
}

\author{
Thomas Schwartz, $†$ MisRi Bin Kusnan $\ddagger$ and Heinrich P. Fock* \\ Fachbereich Biologie, Universität Kaiserslautern, Postfach 3049, D-6750 Kaiserslautern, Germany
}

(Received 14 February 1991; revised 20 May 1991; accepted 4 June 1991)

\begin{abstract}
When grown on ammonia as sole nitrogen source, the basidiomycete fungus Stropharia semiglobata assimilated nitrogen via glutamate dehydrogenase (GDH). The two isoenzymes of GDH were both repressed by increasing concentrations of ammonia, but NADP-GDH (EC 1.4.1.4) was far more active than NAD-GDH (EC 1.4.1.2). Glutamine synthetase (GS; EC 6.3.1.2) and glutamate synthase (GOGAT; EC 1.4.7.1) were also active in $S$. semiglobata and these enzyme activities were independent of the ammonia concentration in the suspension. From enzyme activity and ${ }^{15} \mathrm{~N}$-labelling studies of amino acids, it is concluded that both GDH and GS/GOGAT contribute to ammonia assimilation in this fungus.
\end{abstract}

\section{Introduction}

Inorganic ammonia and nitrate are the natural nitrogen sources preferred by bacteria, algae and fungi. The only known metabolic pathway for utilization of nitrate nitrogen is by reduction first to nitrite and subsequently to ammonia (Pateman \& Kinghorn, 1975); 2-oxoglutarate and glutamate have unequivocally been demonstrated to be the primary organic acceptors for inorganic ammonia (Miflin \& Lea, 1977; Smith et al., 1975; Tyler, 1978). Consequently, the amino acids glutamate and glutamine are formed primarily and serve as donors in transamination and amino group transfer reactions.

Ammonia assimilation in fungi is catalysed by NAD(P)H-specific glutamate dehydrogenase (GDH) with the formation of glutamate, or by glutamine synthetase (GS) with the formation of glutamine.

The amido group of glutamine is often further metabolized and incorporated into glutamate via the glutamate synthase (GOGAT) reaction.

By coupling the GS and GOGAT reactions an almost irreversible route for ammonia assimilation is achieved. Some fungi as well as higher plants form glutamate via the GS/GOGAT pathway, especially when the ammonia

† Present address: Max Planck Institut für medizinische Forschung, Jahnstr. 29, D-6900 Heidelberg, Germany.

$\ddagger$ Present address: Department of Biology, University of Agriculture Malaysia, 43400 Serdang, Selangor, Malaysia.

Abbreviations: GDH, glutamate dehydrogenase, GOGAT, glutamate synthase; GS, glutamine synthetase. supply is limited (Hummelt \& Mora, 1980: Kusnan et al., 1987; Miflin \& Lea, 1980).

In studies on the primary nitrogen metabolism of fungi, yeasts and ascomycetes have been investigated preferentially (Brown et al., 1974; Casper et al., 1985; Dunn-Coleman et al., 1981; Holmes et al., 1989; Kusnan et al., 1987, 1989; Limon-Lason et al., 1977). In this paper the primary nitrogen metabolism of the basidomycetic fungus Stropharia semiglobata was investigated.

\section{Methods}

Organism and growth conditions. Stropharia semiglobata TA 79139 was obtained from T. Anke (University of Kaiserslautern, FRG). It was grown in a culture medium based on those of Garrett (1972) and Jennison et al. (1955), containing $\left(\mathrm{g}^{-1}\right)$ glucose (10), $\mathrm{K}_{2} \mathrm{HPO}_{4} / \mathrm{KH}_{2} \mathrm{PO}_{4}(0 \cdot 96 / 0 \cdot 68), \mathrm{MgSO}_{4} .7 \mathrm{H}_{2} \mathrm{O}(0 \cdot 1), \mathrm{NaCl}(0 \cdot 1)$, $\mathrm{CaCl}_{2} .2 \mathrm{H}_{2} \mathrm{O}(0 \cdot 1)$, biotin $(0.001)$, riboflavin $(0.001)$, thiamin $(0.001)$ and micronutrients according to Nicholas \& Nason (1954). Further details on the growth conditions of the fungus have been published previously (Kusnan et al., 1987, 1989).

$\left[{ }^{15} \mathrm{~N}\right]$ Ammonia incubation. The fungus was grown in 2.5 litres of nutrient solution containing $2 \mathrm{mM}-\mathrm{NH}_{4} \mathrm{Cl}$ as sole nitrogen source. On reaching the experimental growth-phase mycelia were transferred, resuspended in $500 \mathrm{ml}$ of fresh culture medium and diluted to about $1 \mathrm{~g}$ fresh wt per $100 \mathrm{ml}$. After adaptation for $2 \mathrm{~h}$ at $26^{\circ} \mathrm{C}, 500 \mathrm{ml}$ of fungal suspension was diluted with $500 \mathrm{ml}$ of nutrient solution containing ${ }^{15} \mathrm{NH}_{4} \mathrm{Cl}$ (99\% enrichment). Consequently, the ammonia content of the incubation medium was $2 \mathrm{mM}\left(40-50 \%{ }^{15} \mathrm{~N}\right.$ enrichment). The culture media were aerated throughout the incubation period. The ammonia concentration of the media was regularly analysed by withdrawing samples and determining ammonia colorimetrically (Yuen \& Pollard, 1952). 
Harvest for amino acid and total nitrogen determination. After incubation with ${ }^{15} \mathrm{NH}_{4} \mathrm{Cl} 100 \mathrm{ml}$ samples were harvested by filtration through Miracloth (Calbiochem). The mycelia were washed with approximately $100 \mathrm{ml}$ ice-cold $0 \cdot 1 \%(\mathrm{w} / \mathrm{v}) \mathrm{NaCl}$, suspended in $8 \mathrm{ml}$ $95 \%(\mathrm{v} / \mathrm{v})$ ethanol and stored at $-20{ }^{\circ} \mathrm{C}$ until further use.

Extraction and determination of nitrogenous compounds. The mycelia, the total nitrogen of which was determined as ammonia following Kjeldahl digestion, were homogenized with a pestle and mortar in ethanol, quantitatively transferred into a calibrated cylinder and diluted to $15 \mathrm{ml}$ with ethanol. This suspension was diluted to $20 \mathrm{ml}$ with distilled water (final ethanol concentration $70 \%$ ).

Samples $(2.5 \mathrm{ml})$ of the ethanolic fraction were taken to dryness for . dry weight determination. The remaining suspension was centrifuged, the supernatant taken to dryness in a vacuum evaporator at $37^{\circ} \mathrm{C}$ and the residue dissolved in $5 \mathrm{ml}$ of water $(\mathrm{pH} \mathrm{3-5)}$. Amino acids were analysed according to Kedenburg (1971) by using a Beckman Multichrome liquid chromatograph. Acidic amino acids were separated from neutral and basic amino acids on a Dowex 1X8 column $(4 \times 0.9 \mathrm{~cm}$, acetate form $)$. The neutral and basic amino acids passed through the column; after washing the column with $8.0 \mathrm{ml}$ of water, these amino acids were recovered completely. The acidic amino acids were eluted with $8.0 \mathrm{ml} 2 \mathrm{M}$-acetic acid. The water- and acid-eluates were vacuum-dried separately, and each was resuspended in $2 \mathrm{ml}$ lithium hydroxide/citric acid buffer at $\mathbf{p H} 2.2$ for amino acid analysis (Kusnan et al., 1987). ${ }^{15} \mathrm{~N}$ was determined by emission spectroscopy as described previously (Berger \& Fock, 1983). By applying appropriate corrections for isotope dilution arising from ammonia introduced into the analytical procedure ${ }^{15} \mathrm{~N}$ enrichment of total nitrogen in the mycelia and in extracted amino acids as well as of glutamine-amino and glutamine-amido was estimated (Kusnan et al., 1989; Kusnan, 1990).

Enzyme extraction. Mycelium was collected by filtration, washed with 1 litre of water and frozen in liquid nitrogen until use. The frozen tissue was homogenized by pestle and mortar and extracted in potassium phosphate buffer as described by Dunn-Coleman et al. (1981). The extract was desalted on a Sephadex G-25 column equilibrated with the same buffer.

Enzyme assays. The activities of NADP-GDH (EC 1.4.1.4) and NAD-GDH (EC 1.4.1.2) were assayed according to Stewart \& Moore (1974) at pH 7.9 and 8.5, respectively. GS (EC 6.3.1.2) activity was assayed as described by Boland \& Benny (1977). In all cases, activity was determined by following the oxidation of NADH at $340 \mathrm{~nm}$ $\left(30^{\circ} \mathrm{C}\right.$ ). GOGAT (EC 1.4.7.1) activity was assayed both by the transferase and by the synthetase reactions, as described by Ferguson \& Sims (1971, 1974). Specific activities of the enzymes are expressed as nmol reduced coenzyme oxidized or $\gamma$-glutamylhydroxamate formed $\min ^{-1}$ (mg protein) ${ }^{-1}$. Protein was determined colorimetrically by binding to Coomassie Brilliant Blue G-250 (Sedmark \& Grossberg, 1977) with bovine serum albumin as the standard.

\section{Results}

\section{Amino acid and ammonia content}

During exponential growth in $2 \mathrm{mM}-\mathrm{NH}_{4} \mathrm{Cl}$ as sole nitrogen source (growth factor, $\mu,=0.0514 \mathrm{mg}$ dry wt $\mathrm{h}^{-1}, 48-96 \mathrm{~h}$ after inoculation), the mycelium was harvested and extracted, and the amino acid and ammonia content analysed (Table 1). Glutamine was present at by far the highest concentration $(3643 \pm 327 \mathrm{nmol}$ per $100 \mathrm{mg}$ dry wt). The concentrations of the free amino acids glutamate, alanine and
Table 1. Amino acids and ammonia content of $S$. semiglobata grown in $2 \mathrm{mM}-\mathrm{NH}_{4} \mathrm{Cl}$ medium

\begin{tabular}{|c|c|c|c|}
\hline $\begin{array}{l}\text { Amino } \\
\text { acid }\end{array}$ & $\begin{array}{c}\text { Content } \\
(\mathrm{nmol} \text { per } \\
(100 \mathrm{mg} \text { dry wt) }\end{array}$ & $\begin{array}{c}\text { Standard error, SE } \\
(\% \mathrm{SE})\end{array}$ & $\begin{array}{l}\text { No. of } \\
\text { replicates, } n\end{array}$ \\
\hline Aspartate & 457 & $59.9(11.5 \%)$ & 4 \\
\hline Glutamate & 1682 & $256.6(15.2 \%)$ & 5 \\
\hline Threonine & 118 & $5.6(4.7 \%)$ & 4 \\
\hline Serine & 280 & $25.3 \quad(9.0 \%)$ & 6 \\
\hline Asparagine & 306 & $37.2(12.1 \%)$ & 4 \\
\hline Proline & 95 & $14.5(15.3 \%)$ & 4 \\
\hline Glycine & 258 & $21.4 \quad(8.2 \%)$ & 6 \\
\hline Alanine & 1130 & $145.5(12.8 \%)$ & 4 \\
\hline Valine & 170 & $7.5 \quad(4.4 \%)$ & 4 \\
\hline Histidine & 123 & $6.8 \quad(5.5 \%)$ & 5 \\
\hline Glutamine & 3643 & $326.8 \quad(8.9 \%)$ & 5 \\
\hline Arginine & 1185 & $118.5(10.0 \%)$ & 5 \\
\hline Lysine & 257 & $15 \cdot 6 \quad(9 \cdot 1 \%)$ & 4 \\
\hline Ammonia & 986 & $90.0 \quad(9.1 \%)$ & 4 \\
\hline
\end{tabular}

arginine were also high (1200-1700 nmol per $100 \mathrm{mg}$ dry wt). The ammonia content was $982 \mathrm{nmol}$ per $100 \mathrm{mg}$ dry wt.

During $60 \mathrm{~min}$ incubation with $2 \mathrm{mM}^{-15} \mathrm{NH}_{4} \mathrm{Cl}$, the ammonia content of the medium declined insignificantly (from 2.0 to $1.8 \mathrm{mM}$ ) while the ${ }^{15} \mathrm{~N}$ enrichment of the medium remained almost constant (approximately $40 \%$ ${ }^{15} \mathrm{~N}$ ). During this period the mycelial amino acid pools remained fairly constant, and the concentrations measured were similar to those before incubation in ${ }^{15} \mathrm{NH}_{4} \mathrm{Cl}$ (Fig. 1). Therefore, ${ }^{15} \mathrm{NH}_{4}^{+}$uptake and metabolism occurred during steady-state growth of the fungus.

\section{${ }^{15} N$ Uptake}

The total nitrogen content of mycelia during the incubation was $301 \mathrm{nmol} \mathrm{N}$ per $100 \mathrm{mg}$ dry wt tissue (mean of five replicates). The ${ }^{15} \mathrm{~N}$ enrichment of the tissue increased by $4.8 \pm 0.4 \%$ after $70 \mathrm{~min}$ incubation with $2 \mathrm{mM}-\mathrm{NH}_{4} \mathrm{Cl}(40 \%$ enrichment) (data not shown). Based on the average total nitrogen and ${ }^{15} \mathrm{~N}$ enrichment of total nitrogen, about $344 \mathrm{nmol} \mathrm{N} \mathrm{min}^{-1}$ per $100 \mathrm{mg}$ dry wt were assimilated.

Incorporation of ${ }^{15} \mathrm{~N}$ from ${ }^{15} \mathrm{NH}_{4} \mathrm{Cl}$ into soluble amino acids is shown in Figs 2 and 3. After a 10-20 min lag phase, ${ }^{15} \mathrm{~N}$ in glutamate increased steadily and approached a saturation of more than $30 \%$ enrichment after $60 \mathrm{~min}$ incubation. Total ${ }^{15} \mathrm{~N}$ in glutamine (aminoplus amido-nitrogen) increased continuously from zero to $19 \%$ enrichment during $60 \mathrm{~min}$ incubation. This value is lower than the ${ }^{15} \mathrm{~N}$ enrichment in glutamate. However, more ${ }^{15} \mathrm{~N}$ was incorporated into the amide group than into the amino group of glutamine (Fig. 2). The ${ }^{15} \mathrm{~N}$ enrichment of amide increased to $24.5 \%$ compared to a 


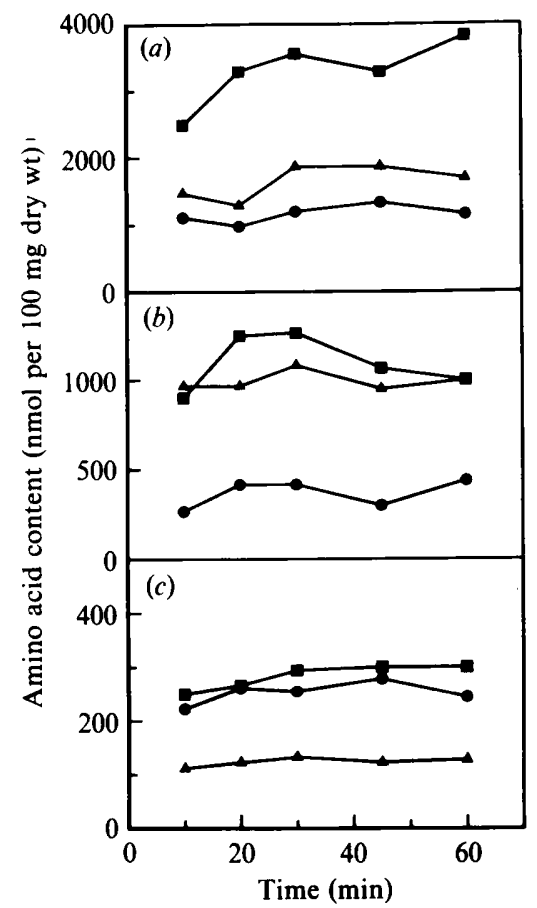

Fig. 1. Amino acid content of $\mathrm{S}$. semiglobata during ${ }^{15} \mathrm{NH}_{4} \mathrm{Cl}$ feeding. The results of one of two replicates with similar trends are shown; the deviation from values shown was about $10 \%(a): \square$, Glutamine; $\boldsymbol{\Delta}$, glutamate; $\boldsymbol{O}$, arginine. (b): $\square$, Alanine; $\Delta$, ammonia; $\boldsymbol{O}$, aspartate. (c): $\square$, Serine; $\mathbf{O}$, glycine; $\boldsymbol{\Delta}$, histidine.

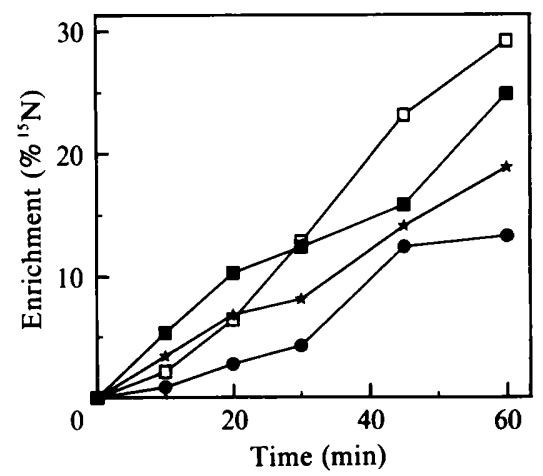

Fig. $2 .{ }^{15} \mathrm{~N}$ labelling of glutamate $(\square)$, glutamine $(\star)$, glutamineamine (O) and glutamine-amide $(\square)$ during ${ }^{15} \mathrm{NH}_{4} \mathrm{Cl}$ feeding $(2 \mathrm{mM}$, approximately $40 \%$ enrichment). The standard errors of the mean $(n=$ 2 or 3 ) were $<10 \%$.

$13.5 \%$ enrichment of the amino group, which is lower than the ${ }^{15} \mathrm{~N}$ enrichment of glutamate.

Aspartate and alanine also became highly ${ }^{15} \mathrm{~N}$ labelled (Fig. 3). The ${ }^{15} \mathrm{~N}$ enrichment of these two amino acids increased steadily and reached values of 26.5 and $26.7 \%$ after $60 \mathrm{~min}$ incubation, respectively. Glycine incorporated more than $30 \%{ }^{15} \mathrm{~N}$ and seemed to approach ${ }^{15} \mathrm{~N}$ saturation after 45-60 min incubation with ${ }^{15} \mathrm{NH}_{4} \mathrm{Cl}$.

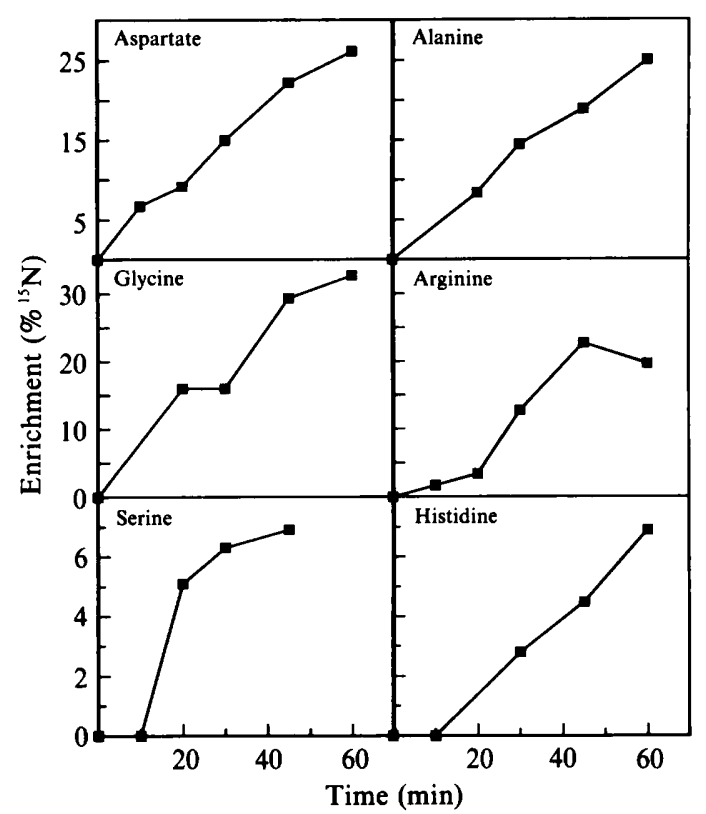

Fig. 3. ${ }^{15} \mathrm{~N}$ labelling of amino acids during ${ }^{15} \mathrm{NH}_{4} \mathrm{Cl}$ feeding $(2 \mathrm{mM}$, $40 \%$ enrichment). The standard errors of the mean $(n=2$ or 3$)$ were $<10 \%$.

Arginine, serine and histidine were labelled only after a lag phase. Then the ${ }^{15} \mathrm{~N}$ label increased, but these amino acids incorporated less ${ }^{15} \mathrm{~N}$ than did glutamine, glutamate, aspartate, alanine and glycine.

\section{Effect of ammonia concentration on the activity of nitrogen-metabolizing enzymes}

Enzyme activities were determined from mycelia grown in media supplied with different concentrations of $\mathrm{NH}_{4} \mathrm{Cl}(2-50 \mathrm{~mm})$. Fig. 4 shows that the activity of NADP-GDH declined with increasing concentrations of $\mathrm{NH}_{4}^{+}$in the medium. Thus $1944 \mathrm{nmol}$ NADPH (mg protein $)^{-1} \mathrm{~min}^{-1}$ were oxidized at $2 \mathrm{mM}-\mathrm{NH}_{4}^{+}$, $1120 \mathrm{nmol}(\mathrm{mg} \text { protein })^{-1} \mathrm{~min}^{-1}$ at $5 \mathrm{mM}^{-\mathrm{NH}_{4}^{+}}$and $368 \mathrm{nmol}(\mathrm{mg} \text { protein })^{-1} \mathrm{~min}^{-1}$ at $50 \mathrm{mM}-\mathrm{NH}_{4}^{+}$.

The change in level of NAD-GDH in response to $\mathrm{NH}_{4}^{+}$ differed greatly from that of NADP-GDH. For NADGDH, the specific activity was $33 \mathrm{nmol}$ NADH (mg protein $)^{-1} \mathrm{~min}^{-1}$ at $2 \mathrm{mM}-\mathrm{NH}_{4}^{+}$, and the activity increased slightly with $10 \mathrm{mM}-\mathrm{NH}_{4}^{+}$in the culture medium. However, the activity declined to $9 \mathrm{nmol}$ NADH (mg protein) ${ }^{-1} \mathrm{~min}^{-1}$ at $50 \mathrm{mM}-\mathrm{NH}_{4}^{+}$.

GOGAT activity was 21 and $30 \mathrm{nmol}$ NADH oxi-

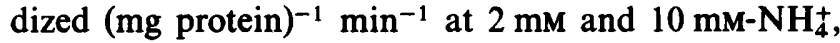
respectively, but declined to $20 \mathrm{nmol}$ (mg protein) ${ }^{-1}$ $\mathrm{min}^{-1}$ at $50 \mathrm{mM}-\mathrm{NH}_{4}^{+}$.

When measured in the transferase assay, GS activity was about 9 times higher than in the synthetase assay; 


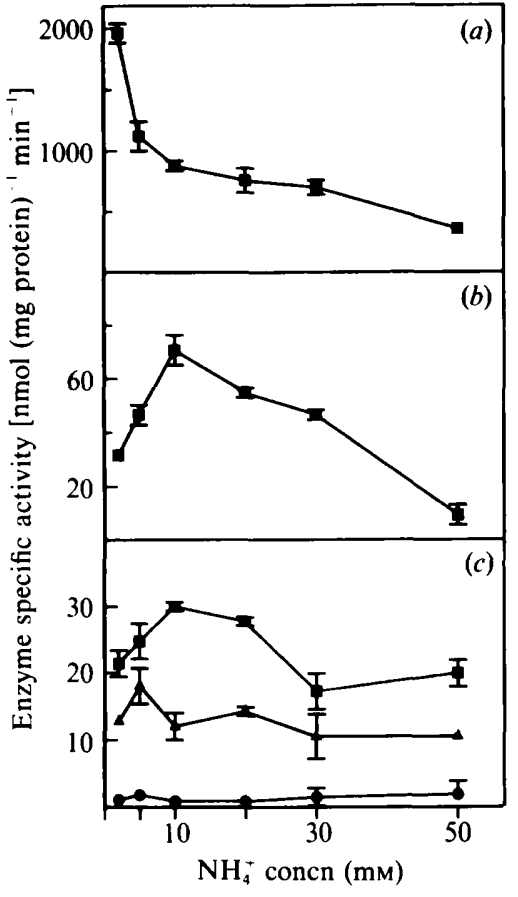

Fig. 4. Enzyme activities of crude extracts of $S$. semiglobata grown at various ammonia concentrations. (a) NADP-GDH. (b) NAD-GDH. (c) : $\square$, NAD-GOGAT; $\triangle$, GS - transferase; , GS-synthetase. Bars represent standard errors.

the activities did not change significantly with the $\mathrm{NH}_{4}^{+}$ concentration in the medium. The activities were about $12 \mathrm{nmol} \gamma$-glutamylhydroxamate formed (mg protein) ${ }^{-1}$ $\mathrm{min}^{-1}$ in the transferase test and $1.2 \mathrm{nmol}(\mathrm{mg} \text { protein })^{-1}$ $\min ^{-1}$ in the synthetase test with $50 \mathrm{~mm}-\mathrm{NH}_{4}^{+}$in the medium.

\section{Discussion}

In this study the capacity of Stropharia semiglobata to incorporate and to metabolize $\mathbf{N H}_{4}^{+}$was investigated. In accordance with investigations from other laboratories, it has been shown that like fungi such as Aspergillus nidulans, Cladosporium sp., Neurospora sp. and Ustilago sp. (Kusnan et al., 1987, 1989; Lewis \& Fincham, 1970a, $b$; Morgan \& MacMillan, 1954; Pateman et al., 1967), S. semiglobata can utilize $\mathrm{NH}_{4}^{+}$as sole nitrogen source.

The mode of entry of ammonia into fungal cells is still obscure, although Pateman et al. (1974) described an active ammonia transporter which together with diffusion may be responsible for ammonia uptake into the fungal tissue.

$S$. semiglobata grew well in media enriched with $\mathrm{NH}_{4} \mathrm{Cl}$, although high concentrations of $\mathrm{NH}_{4}^{+}(50 \mathrm{mM})$ inhibited growth slightly (data not shown). The rate of ammonia uptake was $344 \mathrm{nmol} \mathrm{N} \mathrm{min}$ m $^{-1}$ per $100 \mathrm{mg}$ dry wt, which is $68 \%$ of the uptake rate for $A$. nidulans (Kusnan et al., 1987). The slower rate of ammonia uptake by $S$. semiglobata is reflected by a slower growth rate and longer doubling time $(13.5 \mathrm{~h})$ as compared with $A$. nidulans (7.5 h; Kusnan et al., 1989; Kusnan, 1990).

Several fungi assimulate $\mathrm{NH}_{4}^{+}$through the formation of glutamate by NADP-GDH. $S$. semiglobata also showed GDH activity (Fig. 4). The specific activity of NADP-GDH was approximately 60 times higher than that of NAD-GDH. This result was not unexpected, as A. nidulans (Kusnan et al., 1987) and $N$. crassa (Marzluf, 1981), grown at low concentrations of ammonia, exhibited much higher activities of NADP-GDH than of NADGDH. Because of the different enzyme activities and affinities for ammonia, it appears that NADP-GDH contributes to ammonia assimilation, while NAD-GDH is involved more in the formation of ammonia (Smith $e t$ al., 1975; Stewart et al., 1980).

The alternative pathway of ammonia assimilation via GS/GOGAT has so far been described for only a few fungi. The coupled reactions of this irreversible pathway should assimilate nitrogen very efficiently at low ammonia concentrations (Stewart et al., 1980). GS/ GOGAT activity was found in S. semiglobata (Fig. 4). The GOGAT activities were similar in magnitude to the NAD-GDH activities. This agrees well with the similar activities of GOGAT and NAD-GDH found for $A$. nidulans (Kusnan et al., 1987), Saccharomyces cerevisiae (Roon et al., 1974) and N. crassa (Dunn-Coleman et al., 1981).

GS transferase activities in $S$. semiglobata were low and the synthetase activities even lower (Fig. 4). As some unknown losses of in vivo activities during extraction would be expected and as GS shows a high affinity for ammonia, the measured activities for ammonia fixation appear to be sufficient to maintain the required flux in primary nitrogen assimilation even at high ammonia concentration, when NADP-GDH is strongly repressed. This is obvious as growth of the fungus under these conditions was only slightly reduced.

After 60 min incubation in $2 \mathrm{mM}^{-15} \mathrm{NH}_{4} \mathrm{Cl}$ (approximately $40 \%$ enrichment), glutamate, aspartate, alanine and glycine carried most of the ${ }^{15} \mathrm{~N}$ label (Figs 2 and 3). This is consistent with the operation of highly active aminotransferases in primary nitrogen metabolism (Becker \& Fock, 1989) and transfer of amino groups from glutamate, a primary product of ammonia assimilation, to alanine, aspartate and glycine. The observed high ${ }^{15} \mathrm{~N}$ enrichments in aspartate, alanine, glycine and arginine may be explained by high rates of amino group transfer from glutamate. Aspartate formation in fungi possibly proceeds via glutamate: oxaloacetate aminotransferase 
(Fincham \& Boulter, 1956). Glutamate : pyruvate aminotransferase may catalyse alanine formation from glutamate and pyruvate. Arginine is synthesized from glutamate via ornithine and citrulline (Pateman \& Kinghorn, 1975). Glycine is formed by transamination from alanine and glyoxylate.

After examination of the ${ }^{15} \mathrm{~N}$-labelling kinetics of amino acids, it is apparent that ${ }^{15} \mathrm{~N}$ was incorporated into glutamate with a lag phase while glutamine was labelled more steadily (Fig. 2). Furthermore, much more ${ }^{15} \mathrm{~N}$ was incorporated into the amide group of glutamine than the amino group (Fig. 2). While ${ }^{15} \mathrm{~N}$ in glutamate tended to saturate above $30 \%$ enrichment after $60 \mathrm{~min}$, ${ }^{15} \mathrm{~N}$-labelled amide increased continuously. If NADPGDH, present at high levels, was the only enzyme operative in the fixation of ammonia, a steeper increase in [ $\left.{ }^{15} \mathrm{~N}\right]$ glutamate would have occurred. Therefore, not only NADP-GDH but also GS must have been involved in primary ammonia fixation to form $\left[{ }^{15} \mathrm{~N}\right]$ glutamate as well as glutamine with the amide group preferentially labelled (Rhodes et al., 1980).

When metabolized via GOGAT, the large glutamine pool of $S$. semiglobata will, especially in the early phase of ${ }^{15} \mathrm{NH}_{4} \mathrm{Cl}$ assimilation, dilute glutamate with ${ }^{14} \mathrm{~N}$ and cause the observed lag phage of glutamate labelling. This appears to be the main reason for the observed nearsaturation kinetics of $\left[{ }^{15} \mathrm{~N}\right]$ glutamate labelling below $40 \%$ enrichment. Albeit at a lower level than $\left[{ }^{15} \mathrm{~N}\right]-$ glutamate, ${ }^{15} \mathrm{~N}$-amino-labelled glutamine showed nearsaturation kinetics with a distinct lag phase in the first minutes of the feeding experiment (Fig. 2). This was because glutamine amino-nitrogen was derived slowly from $\left[{ }^{15} \mathrm{~N}\right]$ glutamate. The relatively low ${ }^{15} \mathrm{~N}$ enrichment in glutamine amino-nitrogen may be explained by the large unlabelled glutamine pool (Table 1).

From our results we conclude that, as in other fungi, NADP-GDH and GS/GOGAT are both involved in ammonia assimilation in the basidiomycete $S$. semiglobata. The relative contribution of the GS/GOGAT pathway to ammonia assimilation increases with increasing external ammonia concentration.

We are grateful to Dr T. J. Buckhout for critically reading the manuscript and Deutscher Akademischer Austauschdienst for financial assistance to $\mathbf{M}$. B. Kusnan

\section{References}

BECKER, T. W. \& FoCK, H. P. (1989). Incorporation of ${ }^{14} \mathrm{C}$ and ${ }^{15} \mathrm{~N}$ intermediates of the photorespiratory nitrogen cycle by maize leaves under water stress. Photosynthetica 23, 655-663.

BERGER, M. G. \& FocK, H. P. (1983). Effects of methionine sulfoximine and glycine on nitrogen metabolism of maize leaves in the light. Australian Journal of Plant Physiology 10, 187-194.
Boland, M. J. \& BenNy, A. G. (1977). Enzymes of nitrogen metabolism in legume nodules: purification and properties of NADH-dependent glutamate synthase from lupin nodules. European Journal of Biochemistry 79, 355-362.

Brown, C. M., MacDonald-Brown, D. S. \& Meers, J. L. (1974). Physiological aspects of microbial inorganic nitrogen metabolism. Advances in Microbial Physiology 11, 1-52.

CASPER, P., Bode, R. \& Birnbaum, D. (1985). Untersuchungen zur Regulation der Ammonium-Assimilation von Candida maltosa. Journal of Basic Microbiology 25, 95-101.

Dunn-Coleman, N. S., Robey, E. A., Tomsett, A. B. \& Garrett, R. H. (1981). Glutamate synthase levels in Neurospora crassa mutants altered with respect to nitrogen metabolism. Molecular and Cellular Biology 1, 158-164.

FERGUSON, A. R. \& SIMS, A. P. (1971). Inactivation in vivo of glutamine synthetase and NAD-specific glutamate dehydrogenase: its role in the regulation of glutamine synthesis in yeasts. Journal of General Microbiology 69, 423-427.

Ferguson, A. R. \& Sims, A. P. (1974). The regulation of glutamine metabolism in Candida utilis: the role of glutamine in the control of glutamine synthetase. Journal of General Microbiology 80, 159171.

Fincham, J. R. S. \& Boulter, A. B. (1956). Effects of amino acids on transaminase production in Neurospora crassa: evidence for four different enzymes. Biochemical Journal 62, 72-77.

GARRETT, R. H. (1972). The induction of nitrate reductase in Neurospora crassa. Biochimica et Biophysica Acta 264, 481-489.

Holmes, A. R., Collings, A., Farnden, K. J. F. \& ShePherd, M. G. (1989). Ammonium assimilation in Candida albicans and other yeasts: evidence for activity of glutamate synthase. Journal of General Microbiology 135, 1423-1430.

HUMmelt, G. \& MORA, J. (1980). NADH-dependent glutamate synthase and nitrogen metabolism in Neurospora crassa. Biochemical and Biophysical Research Communications 92, 127-133.

Jennison, M. W., NewCOMB, M. D. \& Henderson, R. H. (1955). Physiology of the wood-rotting basidiomycetes. I. Growth and nutrition in submerged culture in synthetic media. Mycologia 47, 155-274.

KeDENBURG, C P. (1971). A lithium buffer system for accelerated single column amino acid analysis in physiological fluids. Analytical Biochemistry 40, 35-42.

KUSNAN, M. B. (1990). Ammonia assimilation by Aspergillus nidulans and other fungi. PhD thesis, Kaiserslautern University, Germany.

Kusnan, M. B., Berger, M. G. \& Fock, H. P. (1987). The involvement of glutamine synthetase/glutamine synthase in ammonia assimilation by Aspergillus nidulans. Journal of General Microbiology 133, 1235-1242.

Kusnan, M. B., Klug, K. \& Fock, H. P. (1989). Ammonia assimilation by Aspergillus nidulans: $\left[{ }^{15} \mathrm{~N}\right]$ ammonia study. Journal of General Microbiology 135, 729-738.

LEWIS, C. M. \& FINCHAM, J. R. S. (1970a). Regulation of nitrate reductase in the basidiomycete Ustilago maydis. Journal of Bacteriology 103, 55-61.

LewIS, C. M. \& Fincham, J. R. S. (1970b). Genetics of nitrate reductase in Ustilago maydis. Genetical Research 16, 151-163.

Limon-Lason, J., Lara, M., Resendiz, B. \& Mora, J. (1977). Regulation of glutamine synthetase in fed-batch cultures of Neurospora crassa. Biochemical and Biophysical Research Communications 78, 1234-1240.

MARZLUF, G. A. (1981). Regulation of nitrogen metabolism and gene expression in fungi. Microbiological Reviews 45, 437-461.

Mifuin, B. J. \& LeA, P. J. (1977). Amino acid metabolism. Annual Review of Plant Physiology 28, 299-329.

MIfLIN, B. J. \& LEA, P. J. (1980). Ammonia assimilation. In Biochemistry of Plants, vol. 5, pp. 169-202. Edited by B. J. Miflin. London: Academic Press.

Morgan, A. G. \& MacMillan, A. (1954). The assimilation of nitrogen from ammonium salts and nitrate by fungi. Journal of Experimental Botany 5, 232-252.

Nicholas, D. J. \& NASON, A. (1954). Mechanism of action of nitrate reductase from Neurospora crassa. Journal of Biological Chemistry 211, 183-197. 
Pateman, J. A., Dunn, E., Kinghorn, J. R. \& Forbes, E. (1974) Ammonium and methylammonium transport in wild-type and mutant cells of Aspergillus nidulans. Molecular and General Genetics 133, 225-236.

Pateman, J. A. \& Kinghorn, J. R. (1975). Nitrogen metabolism. In The Filamentous Fungi, vol. 2, pp. 159-237. Edited by J. E. Smith \& D. R. Berry. London: Edward Arnold.

Pateman, J. A., Rever, B. M. \& Cove, D. J. (1967). Genetical and biochemical studies of nitrate reduction in Aspergillus nidulans. Biochemical Journal 104, 103-111.

RHODES, D., SIMS, A. P. \& Folkes, B. F. (1980). Pathway of ammonia assimilation in illuminated Lemna minor. Phytochemistry 19, 357365.

Roon, R. J., Even, H. L. \& Larimore, F. R. (1974). Glutamate synthase: properties of the reduced nicotinamide adenine dinucleotide-dependent enzyme from Saccharomyces cerevisiae. Journal of Bacteriology 118, 89-95.

Sedmark, J. J. \& Grossberg, S. E. (1977). A rapid, sensitive and versatile assay for protein using Coomassie Blue G-250. Analytical Biochemistry 79, 544-552.

Smith, E. L., Austen, B. M., Blumenthal, K. M. \& Nyc, J. F. (1975). Glutamate dehydrogenase. In The Enzymes, vol. 11, pp. 293-367. Edited by P. D. Boyer. London: Academic Press.

StewART, G. R. \& MOORE, D. (1974). The activities of glutamate dehydrogenases during mycelial growth and sporophore development in Coprinus lagopus. Journal of General Microbiology 83, 73-81.

Stewart, G. R. ManN, A. F. \& Fentem, P. A. (1980). Enzymes of glutamate formation, glutamate dehydrogenase, glutamine synthetase and glutamate synthase. In The Biochemistry of Plants, vol. 5, pp. 271-327. Edited by B. J. Miflin. London: Academic Press.

TYLER, B. (1978). Regulation of the assimilation of nitrogen compounds. Annual Review of Biochemistry 47, 1127-1162.

Yuen, S. H. \& Pollard, A. G. (1952). Determination of nitrogen in agricultural materials by the Nessler reagent. Journal of the Science of Food and Agriculture 3, 441-447. 